\title{
TILLAGE INTERFERENCE IN THE QUALITY OF PEANUT MECHANIZED HARVEST
}

\author{
Antonio T. S. Ormond ${ }^{1 *}$, Adão F. Dos Santos ${ }^{1}$, Aline S. Alcantara ${ }^{1}$, Cristiano Zerbato ${ }^{1}$, \\ Carlos E. A. Furlani ${ }^{1}$
}

${ }^{1 *}$ Corresponding author. São Paulo State University - UNESP/ Jaboticabal - SP, Brasil. E-mail: tassiormond@gmail.com

\section{KEYWORDS}

digging, statistical process control, losses, gathering.

\begin{abstract}
In Brazil, a large portion of peanut production is found under conventional soil preparation. Due to the fact that there is a lack in studies related to the cultivation of peanuts in conservationists soil preparation, mainly in the field of losses and mechanized harvesting. Thus, it was aimed to assess the quality of digging and gathering operation of peanut, based on losses, using statistical process control techniques in two tillages. The sowing was carried out under conventional and conservationist preparation, revolving only the sowing line. Losses were evaluated in the digging and gathering operation, being that in the gathering it was evaluated the harvest losses in three displacement speeds $(4,6$ and $8 \mathrm{~km} \mathrm{~h}^{-1}$ ) in two tillages. The quality of the process was affected by the soil preparation based on the visible and invisible losses, respectively. Regarding the gathering, the conservationist preparation, it was unstable in all indicators, whereas in the conventional preparation it was noticed reduction of the variability for all the displacement speeds. The peanut sowing under conservationist preparation provided a better quality digging. In contrast, the gathering of pods in areas under conventional tillage showed a better quality of the operation.
\end{abstract}

\section{INTRODUCTION}

The peanut is an important oleaginous in the Brazilian market, having as largest producer the state of São Paulo. The crop in several regions of the state is widely used in rotation systems with sugarcane and pasture reform, and for this reason, conventional soil preparation prevails as the most used. However, some studies have indicated success in the adoption of soil conservationist systems for the crop (Fachin et al., 2014).

Among the main problems affecting peanut cultivation the harvest is the crucial moment because it presents high levels of losses. The harvest is made up of two operations: digging and gathering. In the digging, the pods are removed from the ground by the tractor-diggerinverter that plunks and inverts the plants, forming lines, so that the pods are exposed to the sun for the healing phase and later recollection. Digging losses occur during peanut removal from soil and are influenced by factors such as harvesting time, climate, crop health, maturation, regulation of machinery and mainly soil conditions such as water content and texture (Zerbato et al, 2017).

The second harvesting operation, characterized by the collection and separation of the pods, is carried out by harvester-trailing machine which are similar to those used in the harvesting of beans, which also favor the high levels of crop losses in the harvest and can occur on both the pickup platform, as well as in the trail and cleaning system (Silva et al., 2008).

However, from the technical point of view, the soil preparation system can contribute to the reduction of high levels of crop losses, as well as contribute to the maintenance or improvement of soil quality and to the achievement of satisfactory productivity in the long term (Carvalho et al., 2014). In this way, it is essential that peanut growers are suitable for the preparation that provides the least losses. However, there is a fear by the producers that, over the years, the conservationist tillage will interfere with the digging operation, making it difficult to penetrate the digger in the soil, due to the increasing of the compaction and the vegetation cover on the surface, interfering with the inversion process of the plants during harvest and, consequently, contribute to increased losses (Jackson et al., 2011).

The preparation of conservationist soil aims to reduce the agricultural operations of soil preparation in the ideal period of sowing of the peanut, as well as reduce its costs, since, there are available in the market implements

\footnotetext{
${ }^{2}$ São Paulo State University - UNESP/ Jaboticabal - SP, Brasil.

Received in: 6-13-2017

Accepted in: 2-7-2018
} 
that promote, in a single past, the localized preparation of the sowing line on the straw by simultaneous cutting of the remnants of the previous crop, and soil revolving by scarification (Furlani et al., 2015).

In this way, a scientific support becomes important to break the paradigm created by the producers, mainly on the quality comparis on of the harvesting process, in the soil preparation. In this context, the Statistical Process Control (SPC) is included as a useful and commonly used tool in the analysis of the agricultural processes quality. Several authors have used the SPC, considering the variables evaluated as quality indicators, to identify nonrandom causes or special causes arising from the instability or variability due to the process (Toledo et al., 2013, Paixão et al., 2017; Santos et al., 2017; Zerbato et al., 2017), however, there are no studies evaluating the quality of the peanut harvesting operation in different types of soil preparation.

Thus, based on the assumption that soil preparation may interfere with the quality of the peanut mechanized harvesting process, as well as the loss levels, the objective of this study was to evaluate the quality of mechanized peanut digging and harvesting operations under conventional and conservationist tillage.

\section{MATERIAL AND METHODS}

The experiment was conducted near the geographic coordinates $21^{\circ} 14^{\prime} 54^{\prime \prime} \mathrm{S}$ and $48^{\circ} 16^{\prime} 51^{\prime \prime} \mathrm{W}$, with an average altitude of $568 \mathrm{~m}$ and an average slope of $4 \%$. The soil was classified as typical Eutroferric RED LATOSOLO, clayey texture and smooth wavy relief (EMBRAPA, 2013).

The sowing was done after the preparation of the soil in the areas, being, conventional and conservationist tillage, which constituted the treatments studied. In both areas we used the Granole ic peanut variety, belonging to the botanical group runner.

The conventional tillage consisted of two operations with a heavy disc plough with remote control model GTCR 14x30 (BALDAN, Matão, São Paulo, Brazil). Then, it was realized an operation with a leveling grid model NVCR-E $44 \times 24$ also of the Baldan brand. These operations were adopted for implantation of the peanut crop under conventional tillage because the previous crop of the area was maize, not a sugar cane reforestation area, which requires a large number of operations for the preparation of the conventional soil before the implantation of the peanut crop.

Regarding the conservationist preparation, this was carried out under the remains straw of the corn crop using the Rip Strip implement of 4 lines (KBM - Agricultural Equipments, Dumont, São Paulo, Brazil). In order to prepare the soil, the equipment has six components, each of which is responsible for a function, such as: cutting disc, toothed discs, rod/tip, corrugated discs, wavy discs and ripper/leveler roller. The rods were spaced $90 \mathrm{~cm}$ apart, working at an average depth of $25 \mathrm{~cm}$, with tips 4.8 $\mathrm{cm}$ wide by $16 \mathrm{~cm}$ long.

After the preparation of the soil in the two areas, a pneumatic seeder, model PHL (TATU MARCHESAN, Matão, São Paulo, Brazil) of 8 lines was used, with a line spacing of $90 \mathrm{~cm}$. The sower and all the equipment used in the preparation of the soil were tractioned by a tractor model MF 7370 4X2 with auxiliary front wheel drive
(FWD) and power of 170 hp (AGCO, Ribeirão Preto, São Paulo, Brazil).

As the peanut harvesting takes place in two operations (digging and then gathering the pods), this work was divided in two experiments, aiming to evaluate the interference of the preparation of the soil in each operation.

The losses were calculated according to the gross productivity in each treatment (conventional and conservationist tillage), and productivity was obtained shortly after the digging operation, using a frame of approximately $2 \mathrm{~m}^{2}(1.80 \times 1.11 \mathrm{~m})$, placed on the lines, at 10 sample points per treatment. All material contained within the frame area was cut and bagged, and from the pods found within the sample area, the water content was corrected to $8 \%$ and then the gross productivity was calculated.

\section{Experiment I- Digging}

The digging operation was performed at 120 days after sowing (DAS) by the 2-line C-200 digger/inverter mechanic set (MIAC, Pindorama, São Paulo, Brazil) and a Farmall 95 model tractor, with a power output of $104 \mathrm{hp}$ (Case IH, Assis, São Paulo, Brazil). The operation occurred when the pods presented 70 and $75 \%$ maturation, in the conventional and conservationist tillage, respectively, according to the methodology proposed by Williams \& Drexler (1981).

To characterize the quality of the process, losses were used as a quality indicator. The visible losses in the digging (VLD), invisible losses the digging (ILD) and total losses of the digging (TLD), were determined from the sum of the visible and invisible losses in the digging.

For the data collection of the losses in the digging, 15 points in each treatment were separated from each other by $20 \mathrm{~m}$ using the same frame of the data collection of productivity. The frame was positioned transversely to the line, collecting the loose pods visible on the soil and the pods below the soil, digging to the depth of $15 \mathrm{~cm}$. The definition of the frame width corresponds to the working width of the digger-inverter.

After the collection of the pods, they were placed in paper bags, identified, weighed and sent to a greenhouse, where they remained for 24 hours at $105{ }^{\circ} \mathrm{C}$ (BRASIL, 2009). Then, the loss samples were cleaned and then the loss values were obtained, which were extrapolated to $\mathrm{kg}$ ha $^{1}$, with subsequent correction to $8 \%$ of water content, the value used for the storage of the peanuts in the treatment plants.

\section{Experiment II - Gathering}

The collection was carried out three days after the digging, using the same tractor that did the tillage of the conventional and conservationist soil, model MF 7370 4X2 with au xiliary front wheel drive (FWD) and power of 170 hp (AGCO, Ribeirão Preto, São Paulo, Brazil) which tractioned a peanut harvester model KBM 3384 BR - 4 lines (KBM Agricultural Equipments, Dumont, São Paulo, Brazil).

In this experiment, in addition to verifying the quality of the operation, we also sought to verify the interference of the speed of the machine's displacement in the harvesting operation, according to each tillage. 
The harvester tractor set worked at three shift speeds, 4,6 and $8 \mathrm{~km} \mathrm{~h}^{1}$, these speeds were used to verify the quality of machine operation within the maximum, intermediate and minimum range stipulated by the manufacturer in the manual. In order to obtain the speed the tractor worked with rotation of $2200 \mathrm{rpm}$, and in $2 \mathrm{~A} \mathrm{(4}$ $\left.\mathrm{km} / \mathrm{h}^{1}\right), 2 \mathrm{C}\left(6 \mathrm{~km} / \mathrm{h}^{1}\right)$ and $2 \mathrm{E}\left(8 \mathrm{~km} / \mathrm{h}^{1}\right)$ gears, with speed variation of $\pm 0.50 \mathrm{~km} / \mathrm{h}^{1}$.

The losses were collected in 30 sample points separated by $20 \mathrm{~m}$ in each soil preparation, using a metal frame of approximately $2 \mathrm{~m}^{2}(3.60 \times 0.55 \mathrm{~m})$, following the same principle and standard of the frame used for the loss collection in digging and productivity. After the samples were collected, they were conditioned in identified bags and the dry weight was obtained according to the greenhouse method (BRASIL, 2009). Then the loss values were extrapolated to $\mathrm{kg} \mathrm{ha}{ }^{1}$, with subsequent correction to $8 \%$ water content.

The total losses in the collection were evaluated after the passage of the mechanized set, all the pods being collected inside the frame. Losses from the machine cleaning system and platform losses were considered as total losses, since the sampling method does not allow them to be differentiated.

\section{Statistic}

In order to verify the quality of peanut digging and gathering operations, the quality of the losses was adopted as quality indicators, since the higher the values of these indicators, the lower the quality of the operation.

In both experiments the experimental design adopted followed the premises of the SPC. The collected data were analyzed through descriptive statistics, allowing the analysis of data behavior based on parameters of position and central tendency (mean and median), dispersion (amplitude, standard deviation), coefficient of variation and asymmetry measure ments and kurtos is.

The variability analysis of peanut mechanized harvest was monitored using individual-moving-range (IMR) charts, which contain two graphs: the upper one, corresponding to the individual values sampled at each point, and the lower one, obtained by the calculated amplitude between two successive observations. This type of chart allows the quality of a process to be evaluated by means of the distance between the upper and lower limits, so that the more distant they are from the mean, the greater the variability and consequently the lower the quality.

In order to give greater reliability in the interpretation of the control charts, it was assumed that the data have a normal distribution when the measured values are close to the estimated probability line, which gives a lower error rate in the analysis using control charts of individual model (Noiman et al., 2013), therefore, the Ryan-Joiner normality test was performed at $5 \%$ probability.

\section{RESULTS AND DISCUSION}

\section{Producti vity}

Taking into account that the use of Rip Strip for soil preparation constitutes a technique of conservationist preparation, the yields obtained in the two soil preparation studied, 5000 and $3987 \mathrm{~kg} \mathrm{ha}{ }^{-1}$, conventional and conservationist, respectively, are in agreement with the results found in the literature, since the peanut yield under conventional soil preparation is superior to the conservationist preparation. However, Bolonhezi et al. (2007) observed no difference between conservationist and conventional soil preparation in pod and grain production nor in the number of peanuts reproductive structures. However, peanut cultivation when grown in soils that provide nutritional balance during the cycle, well drained and without physical restrictions, in order to favor the penetration of gypsophors in the soil tend to maximize productivity (Nascimento et al. , 2010), as is the case of conventional soil preparation.

\section{Digging}

The analysis of the parameters of the descriptive statistics (Table 1) shows that the mean and median values for losses in the mechanized peanut digging are close, and that the coefficient of variation is very high, independent of the tillage adopted. However, it is possible to notice that data is normal, according to the Ryan-Joiner test, since the values of kurtosis and asymmetry are low and close to zero.

TABLE 1. Descriptive statistics for quality indicators: visible losses in the digging (VLD), invisible losses in the digg ing (ILD) and total losses in the digging (TLD) in two types of tillage.

\begin{tabular}{ccccccccc}
\hline $\begin{array}{c}\text { Variable } \\
\left(\mathrm{kg} \mathrm{ha}^{-1}\right)\end{array}$ & Mean & Median & $\Sigma$ & Amplitude & CV & Cs & Ck \\
\hline VLD & 94.13 & 85.94 & 49.59 & 155.31 & 52.60 & 0.51 & -0.62 & $0,98^{\mathrm{n}}$ \\
ILD & 141.63 & 152.83 & 50.20 & 176.50 & 35.48 & -0.79 & 0.38 & $0,97^{\mathrm{n}}$ \\
TLD & 235.69 & 241.04 & 81.73 & 264.80 & 34.68 & -0.29 & -0.69 & $0,98^{\mathrm{n}}$ \\
\hline & & \multicolumn{9}{c}{ Conservationist soil preparation } & 71.44 & 0.89 & -0.01 & $0,96^{\mathrm{n}}$ \\
\hline VLD & 82.67 & 60.06 & 59.07 & 202.08 & 40.96 & 0.11 & -0.99 & $0,98^{\mathrm{n}}$ \\
ILD & 115.86 & 115.61 & 47.42 & 160.42 & 50.03 & 0.59 & -0.03 & $0,97^{\mathrm{n}}$ \\
TLD & 198.43 & 192.19 & 99.35 & 343.84 & 59 &
\end{tabular}

$\sigma$ - Standard deviation; CV (\%) - Coefficient of variation; Cs - Asymmetry coefficient; Ck - Coefficient of kurtosis; RJ - Ryan-Joiner normality test similar to Shapiro Wilk (n: normal distribution). 
The high values of the coefficients of variation found are in agreement with those found in the literature when evaluating losses, with CV values in the majority of the studies exceeding 30\%. These high CV values found for harvest losses indicate that for the success of a production system it is essential to maintain and improve the quality of the processes during the harvesting operation, which has high variability rates due to factors inherent in the operation itself, and there may be interaction between the machine, condition of culture and climate, especially labor, as attested by several studies in the literature, regardless of the culture studied, such as peanuts (Zerbato et al., 2017), sugar cane (Toledo et al., 2008) and corn (Oliveira et al., 2014).

In addition, the standard deviation is considered high, indicating that the data is scattered over a wide range of values, evidencing the variability of the process.
However, regarding data variability, Silva et al. (2013) also observed values of amplitude, standard deviation and very high coefficient of variation, fact commonly verified in quantitative evaluations of losses due to the high spatial variability of this type of analysis. It should be noted that the high variability can make a process out of control, so soon, when evaluating crop losses a tool that can help in monitoring the variability and maintenance of process quality are the control charts.

In the control chart for the VLD (Figure 1A) in the digging operation, from the viewpoint of the SPC, in the conservationist soil preparation, it demonstrated instability in the operation, characterized by the point above the upper control limit. In contrast, it can be seen that in the conventional soil preparation, the operation was stable, with all points within the lower and upper control limits.
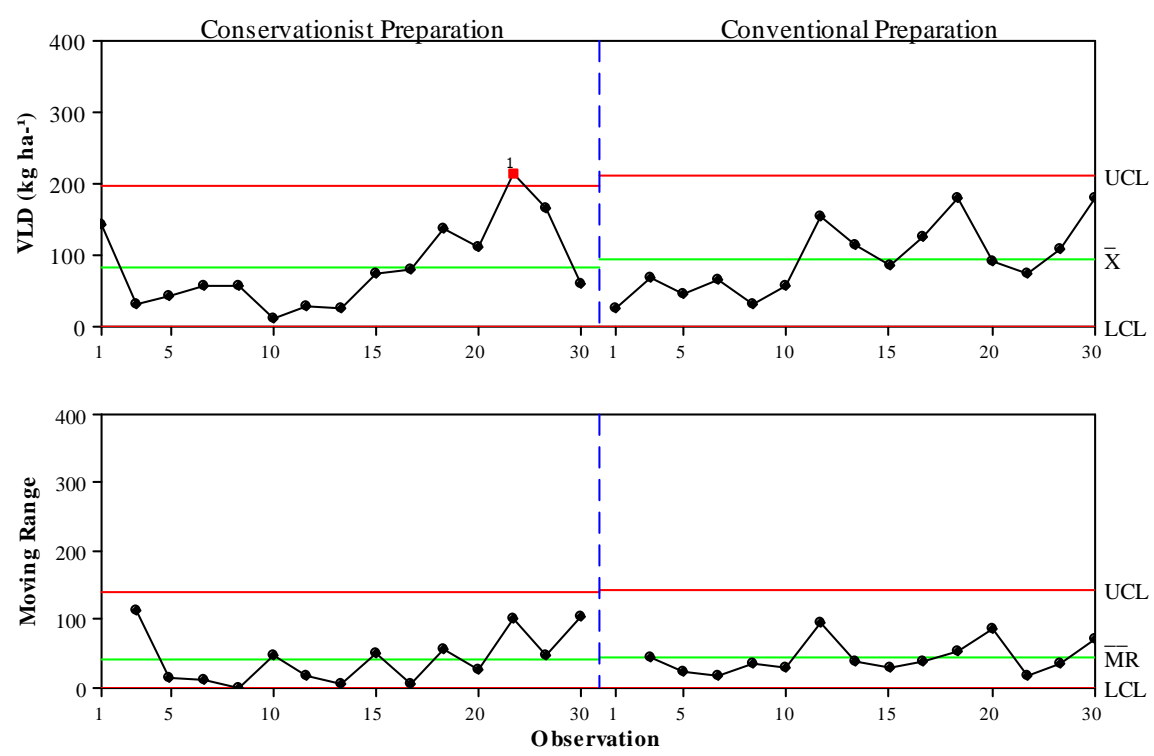

A)
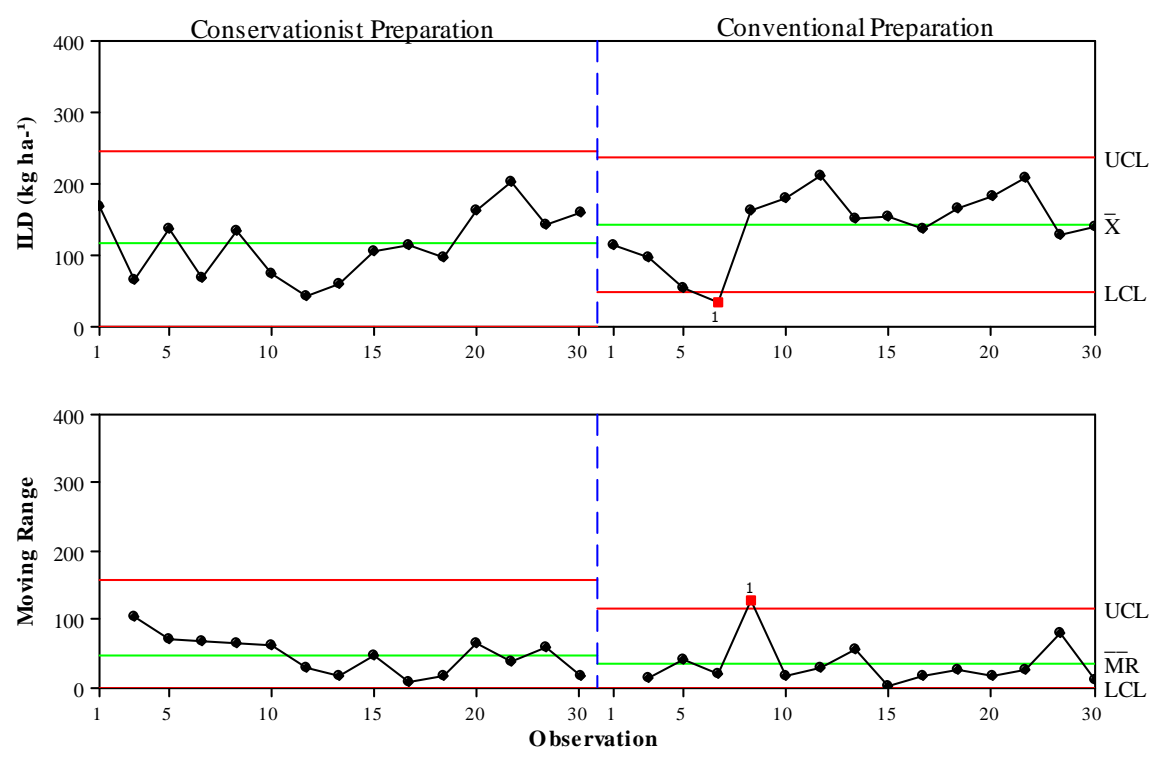

B) 

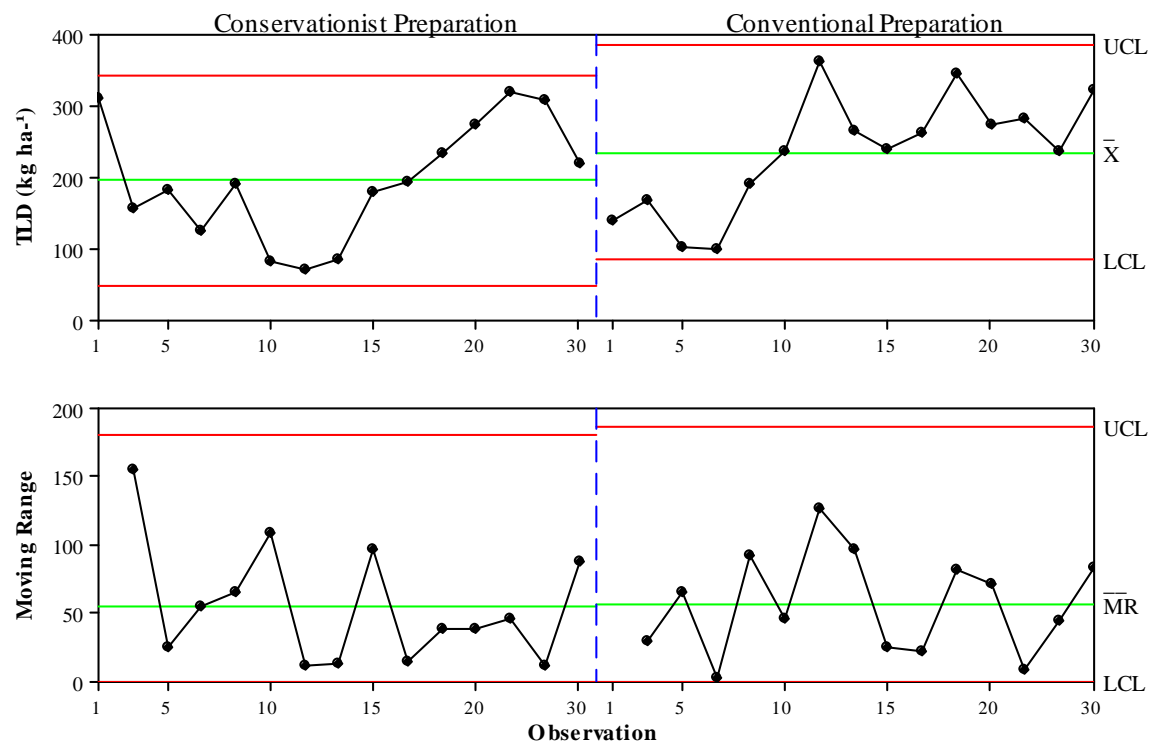

C)

FIGURE 1. Indiv idual control charts and mobile range for visible losses (A); invisible losses (B) and total losses (C).

Despite the instability of the process when carried out under conservationist tillage, it is possible to observe a slight reduction in the variability, confirmed by the mobile range chart. In addition, there is a reduction of $10 \%$ in the average of the visible loss values. The reduction of visible loss levels is associated with an increase in material accumulation on the digging vibrating mat, which, in a way, dampens the impact reducing the detachment of the pods (Santos et al., 2016).

According to Figure 1B, taking into account the ILDs, the digging process under conservationist tillage shows to be stable, that is, without occurrence of points out of control. It is also possible to observe losses with an average value of $115.8 \mathrm{~kg} \mathrm{ha}^{-1}$, and that most of the points sampled were below average, showing that the invisible losses in the digging operation can be reduced by up to $20 \%$ with the maintenance of the vegetative layer on the soil, without interfering with the quality of the process.

On the other hand, the starter under conventional soil preparation presented an unstable process with a point below the lower control limit (LCL). However, the sample value that caused the instability in the process, from the technical point of view of crop losses, can be considered interesting, because the lower the losses, the higher the productivity indexes. Also observing the variability of this process, it is observed that this decreased, proven in the mobile range chart by reducing the upper control limits.

In Figure $1 \mathrm{C}$, both in conventional and conservationist tillage, these were shown to be stable for TLD. This fact can be attributed to the ideal point recommended for the beginning of the peanut crop, which takes into account the maturation of the pods. According to Lamb et al. (2004) TLD in peanut crop can be estimated at $8 \%$ of the total production, but these can reach $40 \%$ when the digging is performed beyond the optimum maturation point. For the present study the values of maturation were $75 \%$ for the conventional and $70 \%$ for the conservationist tillage. Therefore, it can be said that the maturation point can be a good ally of the producer for the reduction in the total losses levels in the digging operation, regardless of the tillage adopted.

In addition, lower variability can be observed for TLDs in conservationist tillage, with lower control limits on individual and mobile range charts, as well as loss reduction. This reduction can be related to the lower soil rotation, since the rotation occurs only in the sowing line, keeping the vegetal remains of the previous crop on the surface, which allows greater infiltration of water in the soil (Prando et al., 2010) which is essential to minimize digging losses.

In the field of peanut crop losses, ILDs occur with greater intensity than VLD, so that these have a strong correlation with TLDs (Santos et al., 2016). As soon as, in the average of each tillage, the total losses were considered low, considering the other studies in the literature, being 4.71 and $4.91 \%$ of the gross productivity in each preparation, conventional and conservationist, respectively.

\section{Gathering}

Based on the descriptive analys is of the losses in the gathering (Table 2), the distribution of data tends to be unnormal, due to the distance between the means and medians, diverging from the asymmetry and kurtosis values close to zero, which indicates data normality, for all speeds, regardless of the tillage, except when the gathering was carried out in the conservationist tillage and at the speed $6 \mathrm{~km} \mathrm{~h}^{-1}$, which presented kurtosis and high asymmetry values. 
TABLE 2. Descriptive statistics of losses $\left(\mathrm{kg} \mathrm{ha}^{-1}\right)$ in the peanut collection in two of soil preparation, for each speed analyzed.

\begin{tabular}{|c|c|c|c|c|c|c|c|c|}
\hline \multirow{2}{*}{ Variable } & \multicolumn{8}{|c|}{ Conventional soil preparation } \\
\hline & Mean & Median & $\Sigma$ & Amplitude & $\mathrm{CV}$ & Cs & $\mathrm{Ck}$ & $\mathrm{RJ}$ \\
\hline $4 \mathrm{kmh}^{-1}$ & 641.81 & 550.8 & 257.81 & 990.88 & 40.17 & 0.76 & -0.12 & $0.96^{\mathrm{n}}$ \\
\hline $6 \mathrm{~km} \mathrm{~h}^{-1}$ & 514.52 & 442.32 & 238.14 & 880.54 & 46.28 & 0.97 & 0.33 & 0.96 \\
\hline \multirow[t]{2}{*}{$8 \mathrm{~km} \mathrm{~h}^{-1}$} & 567.85 & 597.57 & 214.83 & 735.37 & 37.83 & -0.26 & -0.72 & $0.98^{\mathrm{n}}$ \\
\hline & \multicolumn{8}{|c|}{ Conservationist soil preparation } \\
\hline $4 \mathrm{~km} \mathrm{~h}^{-1}$ & 561.2 & 462.5 & 324.4 & 1345 & 58.83 & 1.08 & 1.12 & $0.98^{n}$ \\
\hline $6 \mathrm{~km} \mathrm{~h}^{-1}$ & 465.2 & 495 & 269 & 1210 & 47.87 & 1.32 & 2.4 & $0.95^{n}$ \\
\hline $8 \mathrm{~km} \mathrm{~h}^{-1}$ & 551.8 & 447.5 & 223.4 & 865 & 48.04 & 0.58 & 0.28 & $0.98^{n}$ \\
\hline
\end{tabular}

$\sigma$ - Standard deviation; CV (\%) - Coefficient of variation; Cs - Asymmetry coefficient; Ck - Coefficient of kurtosis; RJ - Ryan-Joiner normality test similar to Shapiro Wilk (n: normal distribution).

Although the velocities of 4 and $6 \mathrm{~km} \mathrm{~h}^{-1}$, in the conservationist preparation had presented the values of high kurtosis, indicating the existence of an agglomeration of the data in the center of the normal distribution curve, characterized as leptokurtic ( $\mathrm{Ck}>0)$, the normality test of Ryan Joyner, revealed that the data of losses in these two velocities also present normal distribution of the data, in both tillage of soils studied. In addition, the positive kurtosis coefficient, although considered in certain high quotations, shows that the values of losses tend to be concentrated around the mean (Cunha et al., 2014), which is interesting in some ways when analyzes the quality of an operation through the SPC, and this condition reduces the variability and increases the quality of the process.

As found in the present study, Cavichioli et al. (2014) also found coefficients of variation for peanut collecting losses very high (> 30\%). The authors considered that this fact is due to the absence of full control of the harvest conditions and, therefore, relates to the natural variability of the harvest process throughout the day.

When there is no constant monitoring of the harvest, regardless of soil preparation and working speed, the results of losses can be significant, making agriculture unfeasible. Thus, taking into account only the losses during the collection, it can be considered that these were high, being approximately 13 and $14 \%$ in the conventional and conservationist tillage, respectively, which justifies the adjustment of the collector throughout the day.

From the control charts for losses in the peanut collection process, points above the upper limit of control (ULC) were observed at a speed of $4 \mathrm{~km} \mathrm{~h}^{-1}$, both for conservationist and for conventional tillage (Figure 2A), making the process unstable. Despite the instability of the process in the two soils tillage analyzed, it was also verified that the conventional preparation showed less variability.
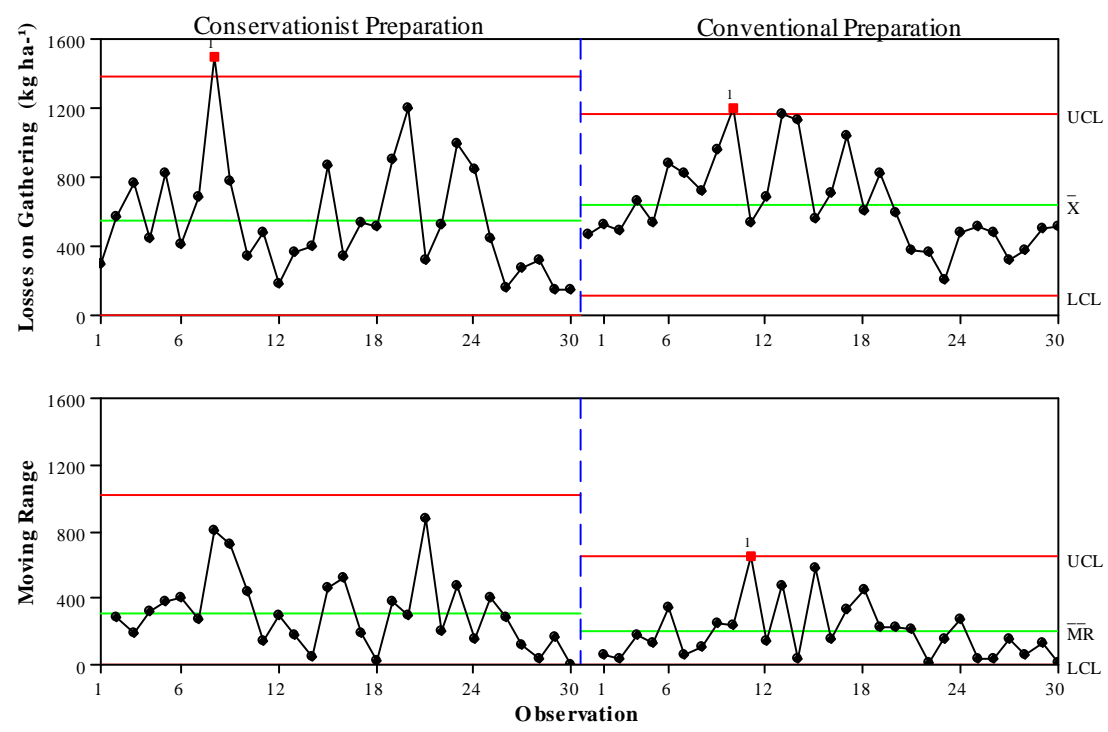

A) 

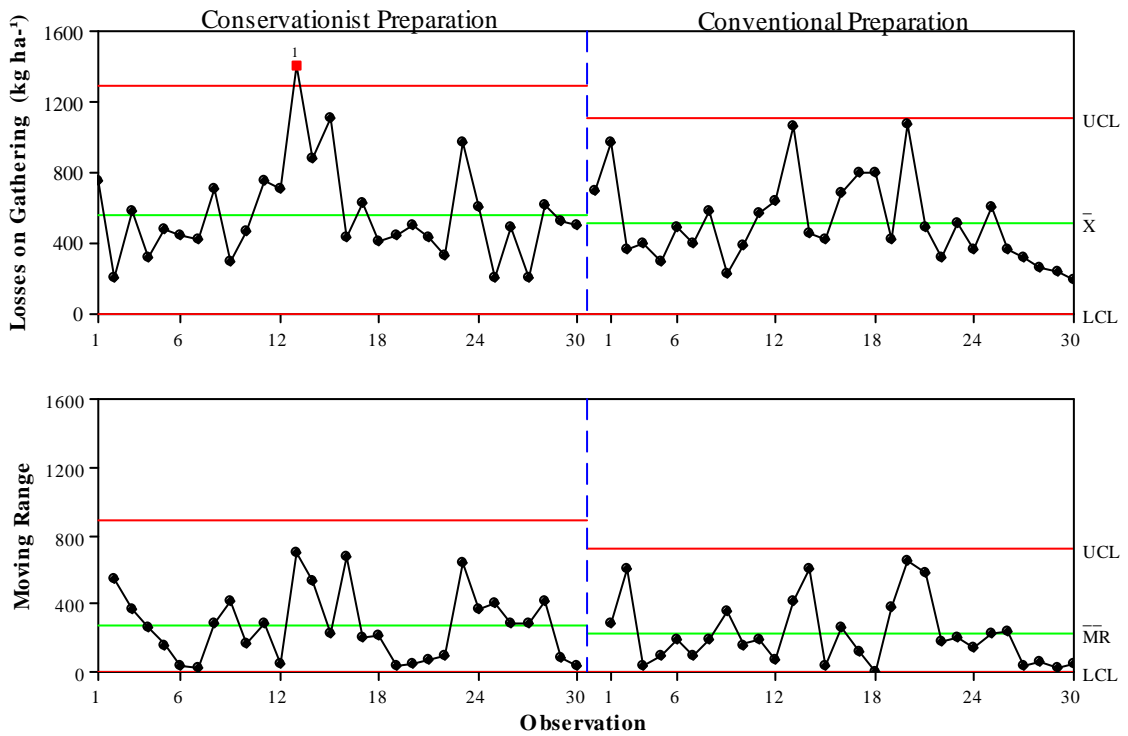

B)
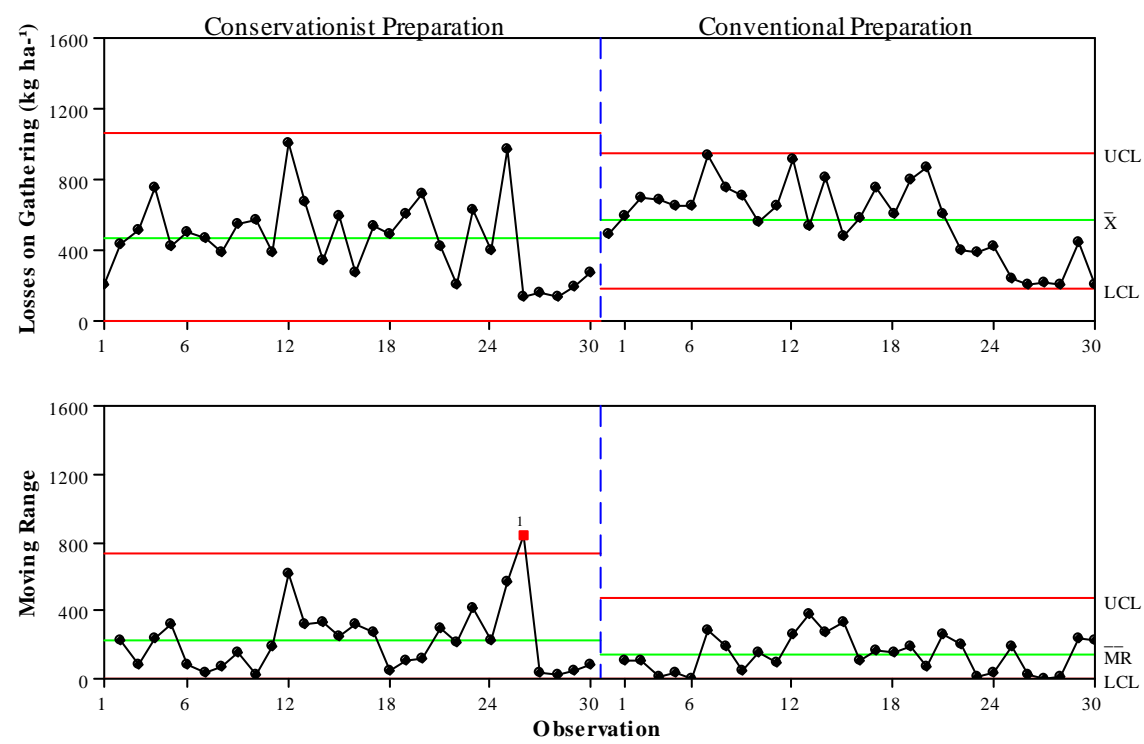

C)

FIGURE 2. Individual control letters and mobile range for peanut collecting losses $\left(\mathrm{kg} \mathrm{ha}^{-1}\right)$ at the $4 \mathrm{~km} \mathrm{~h}^{-1}(\mathrm{~A}), 6 \mathrm{~km} \mathrm{~h}^{-1}$ (B) and $8 \mathrm{~km} \mathrm{~h}^{-1}(\mathrm{C})$ for the conservationist and conventional tillage.

Based on the mobile range charts, it is possible to note the reduction in variability in conventional tillage. This fact can be attributed to the lower water content at the moment of harvesting, while in the conservationist tillage the reduction in the water content of the pods (curing period) may take longer, since the presence of a greater vegetal cover provided in this type of soil preparation allows a greater accumulation of water content in the lines, which makes it difficult to detach the seedlings from the branches at the time of harvest. For one of the main factors that causes losses in the peanut collection is the high water content present in the lines (Cavichioli et al., 2014).

Allied to the aforementioned fact and independent of the soil preparation adopted, harvest losses are also due to the displacement velocity, since the increase or reduction of velocity is intrinsically connected with the water content of the lines. In this way the maintenance of the quality in the harvest depends on the operator's perception, mainly in knowing the working capacity of the machine and operating at speeds appropriate to the state of the crop and the machine itself, making adjustments throughout the day, according to the conditions of temperature and humidity, besides the necessary maintenances (Schanoski et al., 2011).

In the control letters of individual values for losses in the collection at the speed of $6 \mathrm{~km} \mathrm{~h}^{1}$ (Figure 2B), it was verified that the conventional preparation of the soil presented a stable process and of better quality because it presents less variability in relation to the conservationist preparation, in which the process was unstable by the occurrence of a point above the upper control limit, which can be attributed to special causes, such as the interaction of the machine and environmental factors.

The reduction of variability in this case is influenced by the quality of the operation of the digging, which provides better quality and more uniform lines. Moreover, productivity is another factor that contributed to the difference between the loss values, since it has a direct influence on the feed rate of the machine (Souza et al., 2001). 
Silva et al. (2013), evaluating the losses in bean harvesting in two systems of tillage, conventional tillage and no-tillage, with displacement velocity close to $5 \mathrm{~km} \mathrm{~h}^{-}$ 1 , reported that the process was stable in both treatments. In contrast, Toledo et al. (2008), in the mechanized harvest of soybean, found, for the same variable, values out of statistical control. This fact is related to the high values of coefficients of variation found for losses, as mentioned in the digging operation.

In the charts of individual values for the velocity of $8 \mathrm{~km} \mathrm{~h}^{-1}$ (Figure 2C) in the conservationist and conventional preparations, it was observed that there were no points out of control; therefore, the process was stable. However, conventional tillage showed lower variability process with higher average losses compared to conservationists.

For the mobile range charts at velocity $8 \mathrm{~km} \mathrm{~h}^{-1}$, the losses presented different behavior in relation to the individual charts, due to the fact that in the conservationist tillage there was in addition to the greatest variability of the process a point outside the control limits which can be attributed to causes of high process variability.

These results of losses were influenced by the increase of plant material that contributed to the instability and variability of the process, because the increase of the displacement velocity, tends to increase the material flow in the gathering platform of the machine. However, this does not mean that the feed system will completely process this material, since much of it can be lost even before entering the separation and trail system.

Another reas on for increasing above-average losses in the $8 \mathrm{~km} \mathrm{~h}^{-1}$ speed in the conventional tillage is conditioned by the increase in the feed capacity of the harvester-trailer, whereby the speed increase causes the line to be pushed forward by the collector, forming a stack which, when collected, is pressed against the platform base by the collector, causing high losses in gathering (Souza et al., 2001).

\section{CONCLUS IONS}

The conservationist tillage performed using the Rip Strip implement provided a better-quality operation in the peanut digging machining, but the difference between the two tillages does not disqualify the digging under conventional tillage.

For the gathering operation, the conventional tillage presented better quality, with lower losses variability, independent of the displacement speed of the harvestertrailing.

According to the conditions of the present study, the mechanized peanut collection performed at a speed of $8 \mathrm{~km} \mathrm{~h}^{-1}$, independent of the tillage adopted, provided a better-quality process with reduced variability in losses.

\section{REFERENCES}

Bolonhezi D, Mutton MA, Martins ALM (2007) Sistemas conservacionistas de manejo de solo para amendoim cultivado em sucessão à cana crua. Pesquisa Agropecuária Brasileira 42(2):939-947.

BRASIL (2009) Min istério da Agricultura, Pecuária e Abastecimento. Regras para Análise de Sementes. Secretaria de Defesa Agropecuária. Brasília DF, Mapa/ACS. 399p.
Carvalho TL, Rocha AC, Campos BFJ, Cunha FN, Da

Silva NF, Teixeira MB (2014) Genótipos de amendoim cultivados em semeadura direta e convencional sob regime hídrico do sudoeste goiano. Revista Brasileira de Agricultura Irrigada 8(6):432-443. DOI:

http://dx.doi.org/10.7127/rbai.v8n600244

Cavichioli FA, Zerbato C, Bertonha RS, Silva RP (2014) Perdas quantitativas de amendoim nos períodos do dia em sistemas mecanizados de colheita. Científica 42(3):211215.

Cunha JPB, Machado TDA, Santos FL, Coelho LM (2014) Losses in industrial to mato harvesting according to harvester setting. Pesquisa Agropecuária Tropical 44(4):363-369.

EMBRAPA - Empresa Brasileira de Pesquisa Agropecuária (2013) Centro Nacional de Pesquisa de Solos. Sistema Brasileiro de Classificação de Solos. Brasília, Emb rapa, 3 ed. 353p.

Fachin GM, Duarte Júnior JB, Glier CADS, Mro zinski CR, Costa AC da, Guimarães VF (2014) Agronomic characteristics of six peanut cultivars grown in conventional and no-tillage system. Revista Brasileira de Engenharia Agrícola e A mbiental 18(2):165-172. DOI: http://dx.doi.org/10.1590/S 1415-43662014000200006

Furlani CEA, Carne iro FM, Girio LAS, Ormond ATS, Kazama EH, A lcântara AS, Zerbato C (2015) Rip Strip. Cultivar Máquinas 153(8):28-29.

Jackson JL, Beasley Jr JP, Tubbs RS, Lee RD, Grey TL (2011) Fall- bedding for reduced digging losses and improved yield in strip-till peanut. Peanut Science 38(1):31-40. DOI: http://dx.doi.org/10.3146/0095-367938.1 .31

Lamb MC, Masters MH, Rowland D, Sorensen RB, Zhu H, Blankenship PD, Butts CL (2004) Impact of sprinkler irrigation amount and rotation on peanut yield. Peanut Science 31(2): 108-113. DOI:

http://dx.doi.org/10.3146/pnut.31.2.0009

Nascimento IS, Monks PL, Vahl LC, Coelho RW, Silva JB, Fischer V (2010) Aspectos qualitativos da forragem de amendoim forrageiro cv. Alqueire - 1 sob manejo de corte e adubação PK. Revista Agrociência 16(1):117- 123.

Noiman SA, Brown LD, Buja A, Rolke W R, Stine RA (2013) The power to see: A new graphical test of normality. The A merican Statistician 67(4):249- 260. DOI: http://dx.doi.org/10.1080/00031305.2013.847865

Oliveira TC, Figueiredo ZN, Favare HG, Trou i JG, Silva RP (2014) Perdas quantitativas na colheita mecanizada de milho safrinha na região norte de mato grosso. Agrarian Academy 1(2):141-149.

Paixão CSS, Santos AF, Voltarelli MA, Silva RP, Carneiro FM (2017) Times of efficiency and quality of soybean crop mechanical operation in geometry functions of plots. Engenharia Agrícola 37(1):106-115. 
Prando MB, Olibone D, Olibone APE, Rosolen CA (2010) Infiltração de água no solo sob escarificação e rotação de culturas. Revista Brasileira de Ciência do Solo 34(3):693700. DOI: http://d x.doi.org/10.1590/S010006832010000300010

Santos AF, Kazama EH, Ormond ATS, Tavares TO, Silva RP (2016) Quality of mechanized peanut digging in function of the auto guidance. African Journal of Agricultural Research 11(48):4894-4901. DOI: http://dx.doi.org/10.5897/AJAR2016.11442

Santos AF, Silva RP, Tavares TO, Ormond ATS, Rosalen DL, Assis LC (2017) Paralle lis merror in peanut sowing operation with auto-steer guidance Revista Brasileira de Engenharia Agrícola e A mb iental 21(10): 731-736.

Schanoski R, Righi EZ, Werner V (2011) Perdas na colheita mecanizada de soja (Glycine max) no município de Maripá - PR. Revista Brasileira de Engenharia Agrícola e Ambiental 15(11):1206-1211.

Silva RP, Cassia MT, Voltarelli MA, Compagnon AM, Furlani CEA (2013) Qualidade da colheita mecanizada de feijão (Phas eolus vulgaris) em dois sistemas de preparo do solo. Revista Ciência Agronômica 44(1):61-69. DOI: http://dx.doi.org/10.1590/S1806-66902013000100008

Souza CMA, Queiroz DM, Cecon PR, Mantovani EC (2001) Avaliação de perdas em u ma colhedora de flu xo axial para feijão. Revista Brasileira de Engenharia Agrícola e A mbiental 5(3):530-537. DOI: http://dx.doi.org/10.1590/S 1415-43662001000300027
Silva RP, Reis LD, Reis GN, Furlani CEA, Lopes A, Corte z JW (2008) Desempenho operacional do conjunto trator-recolhedora de feijão. Ciência Rural 38(5):12861291.

Toledo A, Silva RP, Furlani CEA (2013) Quality of cut and basecutter blade configuration for the mechanized harvest of green sugarcane. Scientia Agricola 70(6):384389. DOI: http://dx.doi.org/10.1590/S010390162013000600002

Toledo A, Tabile RA, Silva RP, Furlani CEA, Magalhães SC, Costa BO (2008) Caracterização de perdas e distribuição de vegetação em soja mecanizada de colheita. Engenharia Agrícola 28(4):710-719.

Williams EJ, Drexler JSA (1981) A non-destructive method for determining peanut pod maturity. Peanut Science 8(2):134-141. DOI:

http://dx.doi.org/10.3146/i0095-3679-8-2-15

Zerbato C, Furlani CEA, Silva RP, Voltarelli MA, Santos AF (2017) Statistical control of processes aplied for peanut mechanical digging in soil te xtu ral classes. Engenharia Agrícola 37(2): 315-322. DOI:

http://dx.doi.org/10.1590/1809-4430-

eng.agric.v37n2p315-322/2017 